\title{
LASER FLUOROSENSOR FOR OIL SPOT DETECTION*
}

\author{
R. Karpicz ${ }^{\text {a }}$, A. Dementjev ${ }^{\text {a }}$, Z. Kuprionis ${ }^{\text {b }}$, S. Pakalnis ${ }^{\text {b }}$, R. Westphal ${ }^{\text {c }}$, R. Reuter ${ }^{\text {c }}$, \\ and V. Gulbinas ${ }^{\mathrm{a}}$ \\ ${ }^{a}$ Institute of Physics, Savanoriu 231, LT-02300 Vilnius, Lithuania \\ E-mail: vidgulb@ktl.mii.lt \\ ${ }^{\mathrm{b}}$ UAB "Ekspla", Savanoriu 231, LT-02300 Vilnius, Lithuania \\ ${ }^{\mathrm{c}}$ Carl von Ossietzky University of Oldenburg, Institute of Physics, D-26111 Oldenburg, Germany
}

Received 10 May 2005

\begin{abstract}
Oil and water fluorescence properties were studied under their excitation by 266 and $355 \mathrm{~nm}$ light, corresponding to the fourth and third harmonics of a Nd:YAG laser. The oil spill detection fluorosensor designed for onshore or shipboard installation is described and its test results are presented. The fluorosensor enables detection of several $\mu \mathrm{m}$ thick films of different oils and oil products from more than $50 \mathrm{~m}$ distance and $3 \mathrm{~m}$ height above water surface in the daytime.
\end{abstract}

Keywords: fluorescence, oil spill detection, laser

PACS: 07.07.Df, 07.88.+y, 33.50.Dq, 42.68.Wt

\section{Introduction}

Increased consumption and transportation of oil and its products increase the problem of pollution of lakes and oceans. Even the most severe regulation rules of oil transportation cannot prevent the accidents leading to oil spills. Every year about 20 accidents occur, with thousands of tons of oil being spilled into seas, and several accidents every week with tens or hundreds of tons spilled. According to the estimation of oil spill clean up companies, the collection of $1 \mathrm{~kg}$ of oil in the open sea costs about 1 Euro, in coastal waters the price is about 10 times higher, and when oil reaches the shore the oil collection costs increase up to 100 Euro per $\mathrm{kg}$. Therefore, fast detection of oil spill accidents not only saves nature, but also reduces the accident elimination costs.

It is evident that oil spills in coastal waters, harbours, and oil terminals are especially dangerous and particularly fast actions should be taken when such accidents occur. Therefore, reliable oil spill detection systems are very important. Several oil spill control methods based on radio wave reflection suppression, oil fluorescence, or contact electrical sensors have been developed [1] Radio wave radars operate well in open seas, where sea surface waves are stable, but in closed coastal ar-

\footnotetext{
* The report presented at the 36th Lithuanian National Physics Conference, 16-18 June 2005, Vilnius, Lithuania.
}

eas they are much less effective. On the contrary, application of contact electrical or fluorescence sensors is limited to small high-risk areas permitting ship traffic. Remote laser induced oil fluorescence is probably the most reliable method allowing oil detection on any surface. A number of airborne fluorescence lidars have been developed [2-5]. Some of them currently operate to monitor spills in active sea traffic regions. However, airborne lidar exploitation is very expensive and it cannot be performed continuously.

In this paper we analyse oil fluorescence peculiarities and describe a laser fluorosensor for oil spill detection in coastal waters designed for onshore or shipboard installation. Despite less strict safety and reliability requirements in comparison with airborne laser fluorosensors, this method of oil spill detection meets additional difficulties related to the inclined path of rays during sampling, and the strong natural fluorescence of coastal waters.

\section{Oil and water fluorescence}

Oil and its products, illuminated by UV light, show fluorescence in visible and near UV spectral regions. The fluorescence spectra and quantum yield depend on the oil or its product type, the excitation wavelength, and even sampling conditions. For example, the fluorescence properties change due to oil weathering, 


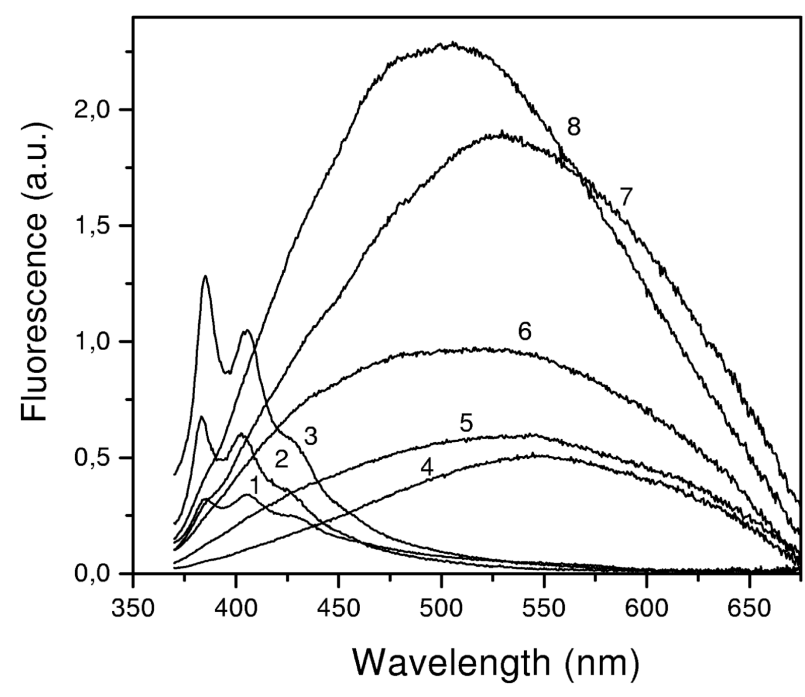

Fig. 1. Fluorescence emission spectra of some oils and oil products excited at $355 \mathrm{~nm}$. 1 - motor oil, 2 - Shell Diala oil, 3 - oil SAE 30, 4 - bunker fuel oil, 5 - Arabian medium crude oil, 6 - Basra crude oil, 7 - German crude oil, 8 - Nihian crude oil.

Table 1. Fluorosensor specification.

\begin{tabular}{cc}
\hline Parameter & Value \\
\hline Weight & $60 \mathrm{~kg}$ \\
Dimensional outlines & $40 \times 60 \times 100 \mathrm{~cm}^{3}$ \\
Scanrate & $1 \mathrm{~Hz}$ \\
Maximum detection distance & $100 \mathrm{~m}$ \\
Excitation wavelength & $355 \mathrm{~nm}$ \\
Excitation energy & $>0.7 \mathrm{~mJ}$ \\
Sampling rate & $200 \mathrm{~Hz}$ \\
Spectral region & $362-732 \mathrm{~nm}$ \\
Number of channels & 6 \\
Voltage supply & $220 \mathrm{~V} \mathrm{AC} \mathrm{or} \mathrm{12} \mathrm{V} \mathrm{DC}$ \\
Power consumption & $100 \mathrm{~W}$ \\
\hline
\end{tabular}

particularly at high temperature when light fractions evaporate. Figure 1 shows fluorescence spectra and relative intensities of different oil types and oil products excited at $355 \mathrm{~nm}$, corresponding to the third harmonics of Nd:YAG laser radiation. The spectra were measured with a Perkin-Elmer LS50B luminescence spectrometer. The samples were placed in $20 \mu \mathrm{m}$ thick quartz cuvettes. The fluorescence spectra of various samples differ significantly and can be used for the oil identification. In practice this information is not sufficient to determine the oil type, but it is sufficient to assign it to one of the oil categories, such as light or heavy oil, crude oil, or some refined products. Generally light oils and refined light oil products emit fluorescence at shorter wavelengths.

Figure 2 shows fluorescence spectra of motor lubricant under 355 and $266 \mathrm{~nm}$ excitation corresponding to the third and fourth harmonics of Nd:YAG laser

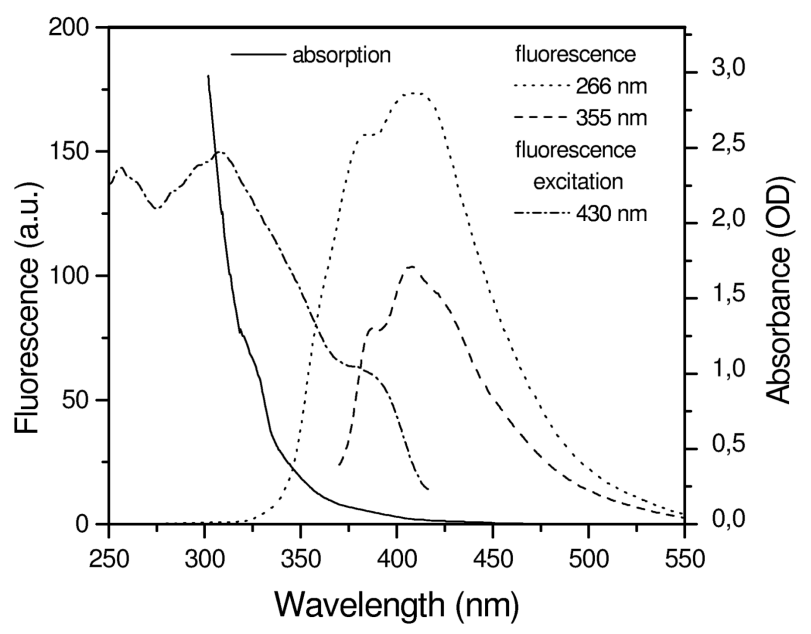

Fig. 2. Absorption (solid line), fluorescence (dotted line $-\lambda_{\text {ex }}=$ $266 \mathrm{~nm}$, dashed line $-\lambda_{\mathrm{ex}}=355 \mathrm{~nm}$ ), and fluorescence excitation detected at $430 \mathrm{~nm}$ (dashed-dotted line) spectra of motor lubricant. The layer thickness was $20 \mu \mathrm{m}$.

radiation. The fluorescence intensity is stronger and slightly shifted to the shorter wavelength side under $266 \mathrm{~nm}$ excitation. This is particularly true for the refined oil products. Figure 2 also shows absorption spectrum of motor lubricant and its fluorescence excitation spectrum obtained at $430 \mathrm{~nm}$ fluorescence detection wavelength. Optical density of the oil layer increases dramatically below $350 \mathrm{~nm}$. The fluorescence excitation spectrum shows that the fluorescence intensity increases with reducing the excitation light wavelength. However, this increase is less dramatic than the increase in the absorption spectrum. This is explained by the $20 \mu$ m thick oil layer that almost completely absorbs the light shorter than $350 \mathrm{~nm}$, which leads to a weak dependence of the fluorescence intensity on the excitation wavelength in this spectral range. One could expect much stronger dependence in the case of very thin layers, which weakly absorb longer wavelength light.

Figure 3 shows fluorescence spectra of water samples taken from different water basins. The spectra are quantitatively similar, only the fluorescence intensity of seawater is lower. The fluorescence originates from the plant decay products known as chromophoric dissolved organic matter (CDOM), or yellow substance [5]. Evidently spectral properties of the yellow substance in fresh water and seawater are similar. Moreover, the yellow substance fluorescence spectrum is quite similar to the spectra of some oils. This is to be expected, since the oil is also formed from plant decay products. Qualitatively similar oil and water fluorescence spectra make oil fluorescence detection in coastal waters containing large amounts of yellow substance a non-trivial task. 


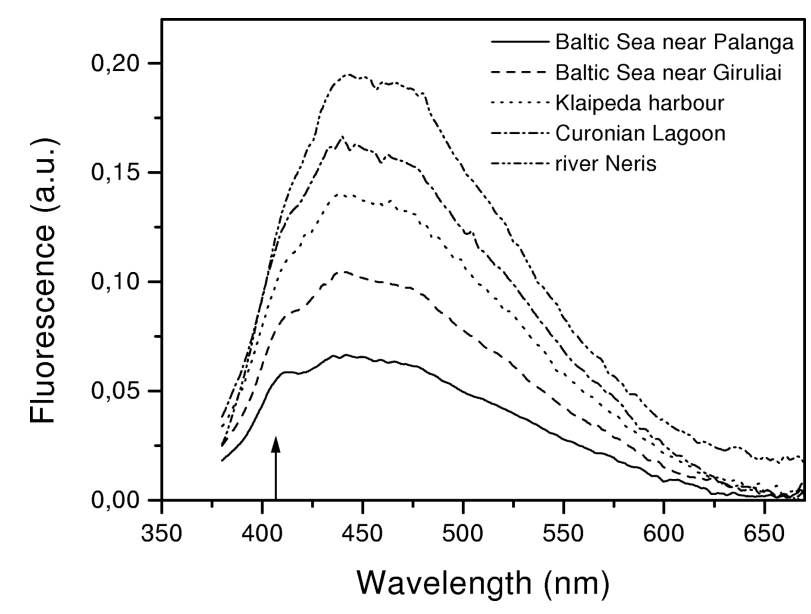

Fig. 3. Fluorescence spectra of water from different places. The arrow indicates the spectral position of the water Raman scattering band (406 nm).

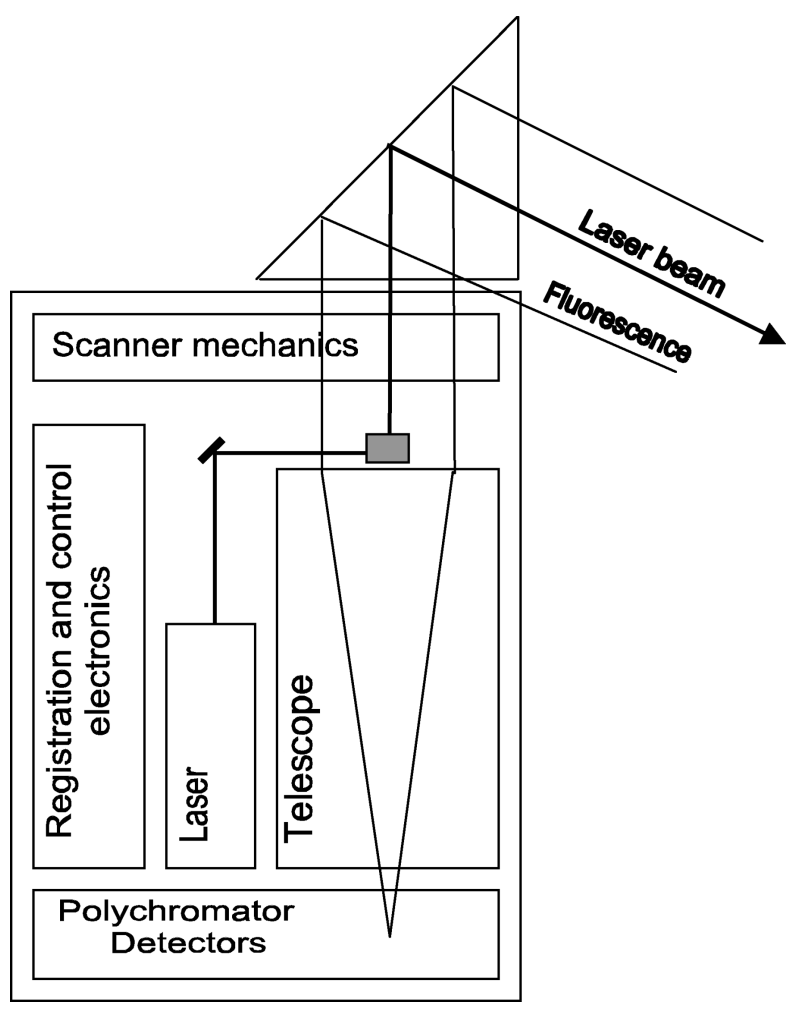

Fig. 4. Block-scheme of the laser fluorosensor.

\section{Oil fluorosensor description}

The block-scheme of the fluorosensor used in the current investigation is shown in Fig. 4. It consists of a laser with beam formation and direction optics, scanner, telescope, spectrograph, registration electronics, and a computer. Third and fourth harmonics of the diode pumped, $Q$-switched Nd:YAG laser radiation are used. Table 1 summarizes the main fluorosensor parameters. A $20 \mathrm{~cm}$ diameter Cassegrian type Mead
8 telescope is used. Fluorescence light collected by the telescope is directed to the polychromator. Based on a diffraction grating the polychromator splits the collected light into 6 channels. The channel spectral ranges are: $366-395 \mathrm{~nm}, 395-433 \mathrm{~nm}, 443-480 \mathrm{~nm}$, $490-555 \mathrm{~nm}, 570-640 \mathrm{~nm}, 636-740 \mathrm{~nm}$. The light is detected by photomultipliers. The periscope-type scanner enables the sampling direction to be varied. In a fast scanning mode it scans a $120^{\circ}$ swath width at a $1 \mathrm{~Hz}$ repetition rate. Construction of the scanner ensures ppolarization of the excitation beam independently of the scanning angle. Due to lower reflection from water or oil surface p-polarized excitation light more efficiently penetrates into the oil volume and creates significantly stronger fluorescence.

Several technical solutions enable the sunlight influence to be suppressed. The viewing angle of the telescope only slightly exceeds the excitation beam divergency. In order to protect photomultipliers from saturation the high voltage is applied in $4 \mu$ s duration pulses synchronized with the laser pulses. Photomultiplier signals are integrated during 100-300 ns time-gates, which are adjusted relative to the laser pulse by taking the sampling distance into account. The measurements are performed during the laser pulse as well as between pulses. The "idle" measurements sample the daylight background. This signal is subtracted from the fluorescence signal. These measures enable oil fluorescence detection under bright daylight conditions, even when the sunlight is directly reflected from the water surface to the detection system.

For shipboard application the fluorosensor is equipped with a horizontal position stabilizer maintaining the horizontal scanner position when the boat swings.

\section{Fluorosensor performance results}

The ability of the fluorosensor to detect oil of different types was tested in simulated "out-of-doors" conditions. The equipment was situated in the laboratory and the oil sample was placed at a distance of $35 \mathrm{~m}$. The samples were made by pasting an oil layer on the carefully cleaned nonluminescent metal sheet. Third or fourth harmonics of fundamental laser radiation was used for the sample excitation. The pulse energy of the third and fourth harmonics radiation was 0.37 and $0.2 \mathrm{~mJ}$, respectively. The test results are summarized in Fig. 5. Despite lower steady-state fluorescence intensity under $355 \mathrm{~nm}$ excitation, the fluorescence intensity obtained with the third harmonic laser excitation of thick oil layers was stronger. Only a thin SAE 


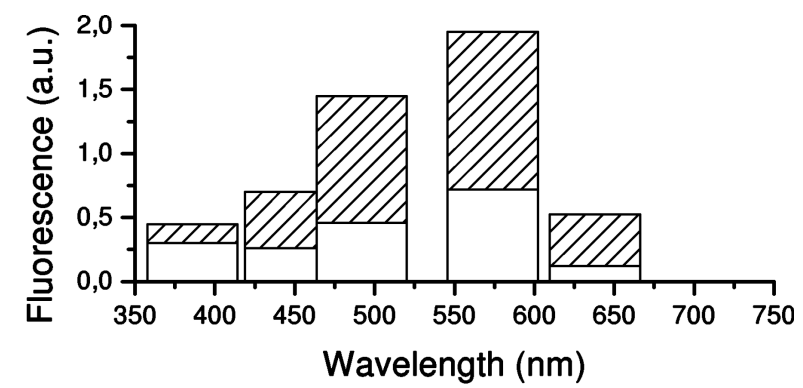

(a)

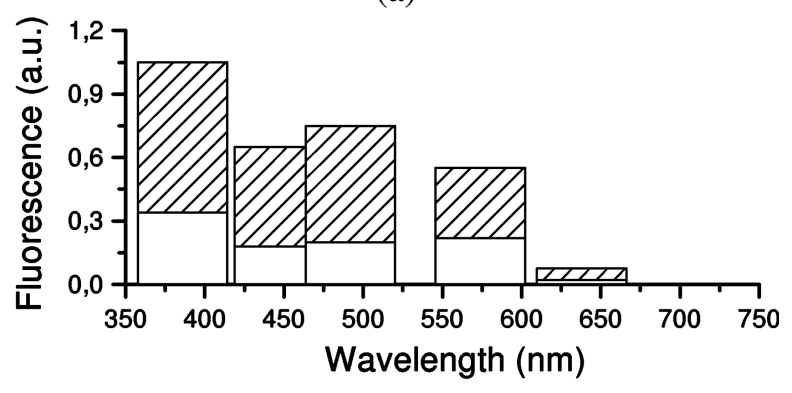

(b)

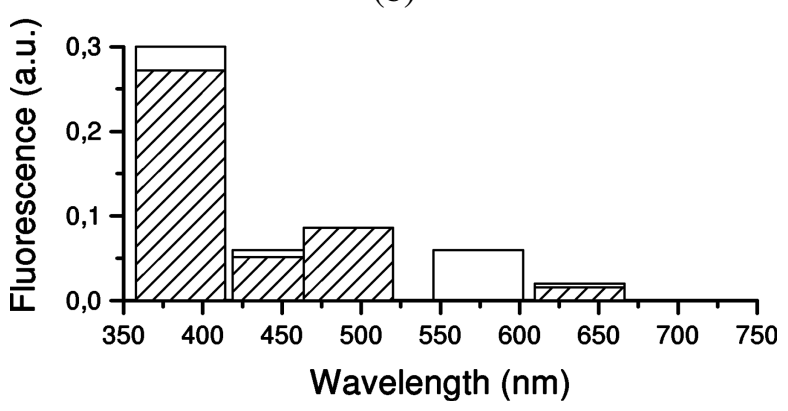

(c)

Fig. 5. Fluorescence spectra of (a) $50 \mu \mathrm{m}$ thick Nihian crude oil layer, (b) $50 \mu \mathrm{m}$ thick SAE 30 oil layer, and (c) $15 \mu \mathrm{m}$ thick SAE 30 oil layer, measured with the laser fluorosensor in laboratory conditions. Fluorescence spectra, shown by light white bars, were excited with the fourth harmonic $(266 \mathrm{~nm})$ light, those by striped bars - with the third harmonic $(355 \mathrm{~nm})$ light.

30 oil layer showed slightly stronger fluorescence under fourth harmonic excitation. Although $266 \mathrm{~nm}$ light is better absorbed and thin oil films show stronger fluorescence, these results show that oil layers of several tens of $\mu \mathrm{m}$ and thicker are slightly better to detect under third harmonic excitation, because of its higher energy. Moreover, third harmonic light is less scattered by fog and aerosols.

The fluorosensor was further tested in various water basins: in the river Neris, Skaistis Lake, the Curonian Lagoon, the Baltic Sea, and at an oil terminal. Results of tests in the daytime in Skaistis Lake are presented in Fig. 6. The fluorosensor was situated $3 \mathrm{~m}$ above the water surface and the laser beam was directed to the water surface from a distance of $35 \mathrm{~m}$. The wind created $5-10 \mathrm{~cm}$ high waves. The third harmonic was used for excitation. In order to form a thin homogeneous oil film the oil samples were dissolved in ethyl ether at a concentration of $1: 10.3 \mathrm{ml}$ of the solution was spilled on the water surface at the laser beam position. The solution rapidly spread to an area of $1-2 \mathrm{dm}^{2}$, and ether evaporated forming several $\mu \mathrm{m}$ thick oil films. This film remained for several seconds, which was sufficient to measure its fluorescence. Later on, the film spread to an area of about $1 \mathrm{~m}^{2}$ forming a sub-micron film.

Figure 6 shows the time sequences of the fluorescence signals obtained by spilling motor lubricant. The water shows clearly observable fluorescence from yellow substance. Instability of the signals is mainly caused by the waves formed by wind on the water surface. It should be noted that waves, in addition to signal instability may significantly increase the sampling distance as proposed in [6]. At the moment when the oil sample was spilled the fluorescence signal increased, but this increase was comparable to that caused by waves. However, relative intensities of the signals in different channels changed significantly. The inserts in Fig. 6 show fluorescence spectra before and after oil spilling. The spectra differ significantly, enabling quite reliable oil spill detection. Similar results were obtained with several crude oils and vegetable oil. Even weakly fluorescent vegetable oil showed fluorescence strong enough to distinguish it from the natural water fluorescence. However, the oil fluorescence rapidly disappeared as the spot spread forming a sub-micron film.

\section{Conclusions}

A laser-induced fluorescence based oil spill detector for onshore or shipboard application was designed and its operation was tested. Laboratory and field tests showed that the fluorosensor enables detection of several $\mu \mathrm{m}$ thick films of different oils and their products from a distance of more than $50 \mathrm{~m}$ and $3 \mathrm{~m}$ height above the water surface in the daytime. The sampling distance may be increased up to $100 \mathrm{~m}$ if much thicker films are to be detected.

\section{Acknowledgement}

This work has been supported by the Fifth Framework Programme of the European Community, contract No EVK3-CT-2002-30001. 


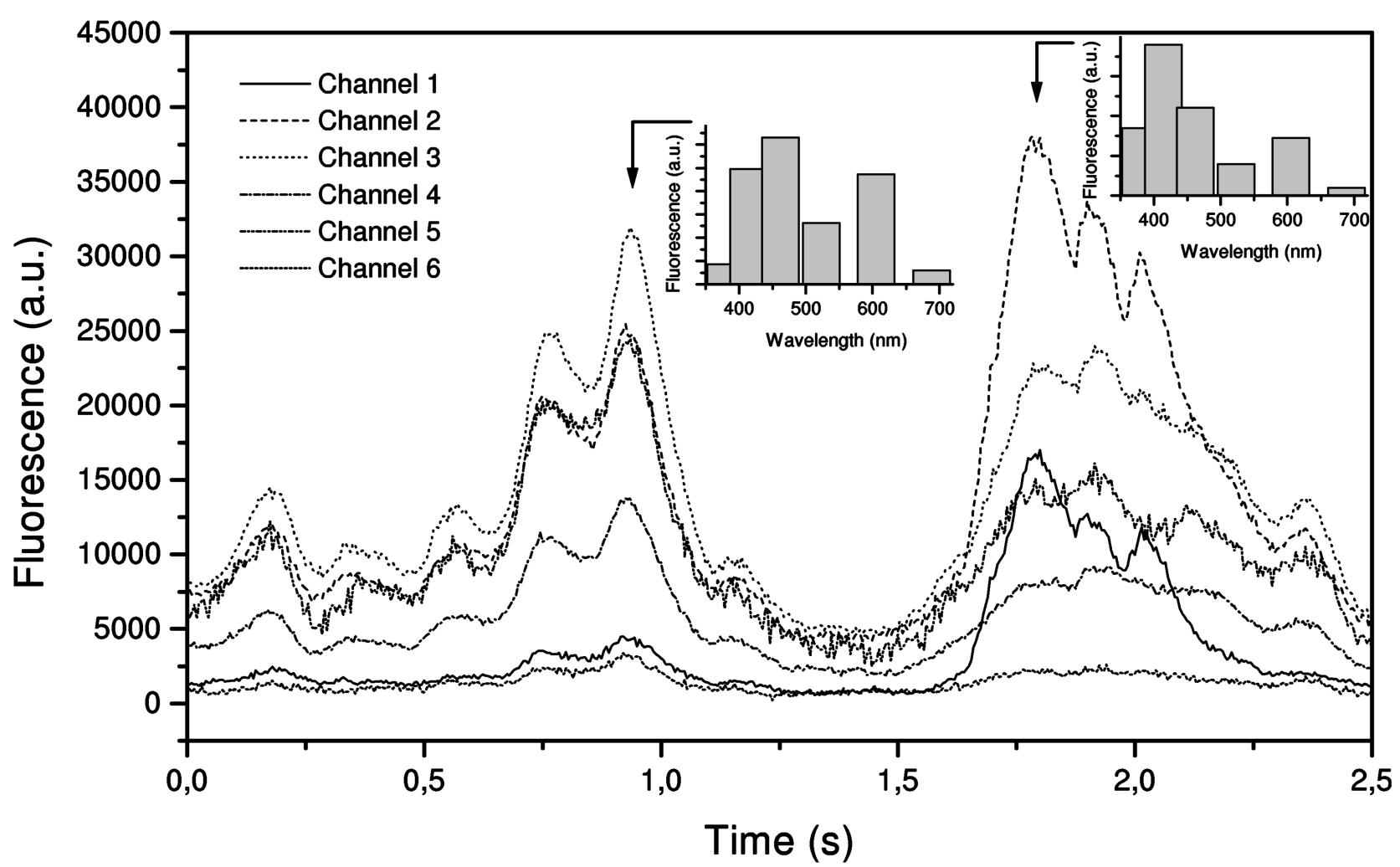

Fig. 6. Real time measurements of Skaistis Lake water fluorescence. At $1.7 \mathrm{~s}$ time $10 \mathrm{ml}$ of motor lubricant was spilt. Inserts show fluorescence spectra at 0.9 and $1.8 \mathrm{~s}$ time.

\section{References}

[1] C.E. Brown, M.F. Fingas, and R.H. Goodman, Oil spill remote sensors: New tools that provide solutions to the old problems, in: Proceedings of the Twenty First Arctic Marine Oil Spill Program Technical Seminar (Environment Canada, Ottawa, Ontario, 1998) pp. 783-794.

[2] T. Sato, Y. Suzuki, H. Kashiwagi, M. Nanjo, and Y. Kakui, Laser radar for remote detection of oil spills, Appl. Opt. 17, 3798-3803 (1978).

[3] R.A. O'Neil, L. Buja-Bijunas, and D.M. Rayner, Field performance of a laser fluorosensor for the detection of oil spills, Appl. Opt. 19, 863-870 (1980).
[4] T. Hengstermann and R. Reuter, Lidar fluorosensing of mineral oil spills on the sea surface, Appl. Opt. 29, 3218-3227 (1990).

[5] F.E. Hoge, A. Vodacek, R.N. Swift, J.K. Yungel, and N.V. Blough, Inherent optical properties of the ocean: Retrieval of the absorption coefficient of chromophoric dissolved organic matter from airborne laser spectral fluorescence measurements, Appl. Opt. 34, 7032-7037 (1995).

[6] S.A. Burikov, D.V. Klimov, P.N. Litvinov, D.V. Maslov, and V.V. Fadeev, Shore-based lidar for monitoring coastal sea, water areas, Quantum Electron. 31, 745750 (2001). 


\title{
LAZERINIS FLUORIMETRAS NAFTOS TARŠOS DETEKCIJAI
}

\author{
R. Karpicz ${ }^{\text {a }}$, A. Dementjev ${ }^{\text {a }}$, Z. Kuprionis ${ }^{\text {b }}$, S. Pakalnis ${ }^{\text {b }}$, R. Westphal ${ }^{\text {c }}$, R. Reuter ${ }^{\text {c }}$, V. Gulbinas ${ }^{\text {a }}$ \\ ${ }^{\text {a }}$ Fizikos institutas, Vilnius, Lietuva \\ b UAB "Ekspla", Vilnius, Lietuva \\ ${ }^{\mathrm{c}}$ Fizikos institutas, Oldenburgas, Vokietija
}

\section{Santrauka}

Augant naftos produktų išgavimo ir transportavo mastams didejja ir vandens telkinių tarša naftos produktais. Norint kuo efektyviau kovoti su vandenynų, jūrų bei uostų tarša, reikia sparčios ir patikimos sistemos, kuri signalizuotu apie naftos produktu išsiliejimą. Efektyvią naftos produktu išsiliejimą registruojančią sistemą i̇manoma sukurti naftos fluorescencijos metodo pagrindu. Tam reikia ultravioletinę šviesą (UV) generuojančio lazerio ir naftos fluorescenciją registruojančios aparatūros. Tokiu prietaisu galima aptikti išsipylusią naftą arba jos produktus ne tik ant vandens paviršiaus, bet ir ant kitu paviršių. Fizikos institute, vykdant Europos 5-osios bendrosios programos projektą ir bendradarbiaujant su UAB EKSPLA bei Vokietijos, Prancūzijos ir Suomijos mokslininkais ir mažų technologiniu įmonių specialistais, sukurtas naftos taršos vandenyje aptikimo ir pirminio apibūdinimo nuotolinis fluorimetras. Fluorimetre panaudojus didelio našumo kompaktišką diodais kaupinamą lazerị, sukurtas daugiakanalis registracijos įrenginys ir efektyvi šviesos surinkimo sistema. Išbandytos šio prietaiso galimybès aptikti įvairių rūšių naftą ir jos produktus priklausomai nuo matavimo atstumo, naftos plèvelès storio, vandens telkinio savybių ir oro sąlygų. 